ordinary variable pupil or was an artificial pupil used? Further, were the tests done so frequently that the figures quoted in the paper have some real numerical value? These are all questions about which nothing is said in the paper. Neither is any reason given for the fact that comparison was made with Landolt's broken ring. What are wanted are the minimum angles which the letters should subtend at the eye in order that they should be read correctly by a skilled observer with perfect vision under standard conditions of illumination, pupil, etc.

Taking, however, the figures given at their face value there are three other criticisms to be offered :-

(1) That $\mathrm{C}$ appears twice in the list of block letters, having a visual value of 0.79 in one place and one of 0.92 in another.

(2) That letters varying greatly in difficulty are included in the selected list. Thus among the 16 letters recommended, are $\mathrm{T}$ the visual value of which is given as 0.74 , and $\mathrm{H}$ with one of 0.92 , i.e., a variation of about 20 per cent. This variation would appear to be too large; it would be preferable to limit the number to the 9 letters:- $\mathrm{V}, \mathrm{U}, \mathrm{Y}, \mathrm{F}, \mathrm{P}, \mathrm{D}, Z, \mathrm{~N}, \mathrm{E}$, which from the values given in the paper vary by under 10 per cent.

(3) The recommendation that letters be used which conform to Snellen's standard perpetuates the old square letter. This shape is stated to be distinctly inferior to that of Green's type in which the shape of the letter is given by:-height 5 minutes and width 4 minutes. This is also apparently the opinion of the committee appointed by the Council of British Ophthalmologists to consider test types.

It may, therefore, be said, that while there is no doubt that the letters of the alphabet vary in difficulty and that for purposes of sight testing a number should be selected which are approximately equally difficult, it is somewhat doubtful, owing to the scanty evidence given by Dr. Ewing, if the recommendations of the American Medical Association really meet the case.

\title{
Glasgow Eye Infirmary
}

In 1924 the Glasgow Eye Infirmary will have completed one hundred years of existence as an institution. In view of this interesting centenary Dr. Leslie Buchanan recently contributed to the Glasgow Herald a short article dealing specially with the beginnings of the infirmary under William Mackenzie and George Monteath, but carrying the history of the institution up to the time of Thomas Reid, who became surgeon in 1868. This article has been reprinted in the Glasgow Medical Journal for March, 1923, where it may be more accessible for professional readers than in the 
Glasgow Herald. Further, the reprint contains very fine reproductions of portraits of Mackenzie, Monteath and Harry Rainy, which did not appear in the lay paper. This little history of the Glasgow Eye Infirmary is of the utmost interest, dealing as it does with the days when modern ophthalmology was in its infancy. Not the least interesting part of it deals with the extraordinarily wide reputation of Mackenzie, of which several examples are given. In one case, about twenty-four years after Mackenzie's death, an old man walked from Warrington to Glasgow, not, it is true, to see Mackenzie but his successor Reid. "He expressed himself as entirely satisfied at having had advice and seen Dr. Reid, who had followed the great Mackenzie, and proposed starting back for Warrington at once, with a bottle of Mackenzie's lotion and a pot of ointment in his pocket, in perfect faith that he was now at last on the safe road to recovery. A word to Dr. Reid resulted in his being 'kept in' for a week or two, and his gratitude was wonderful." In another case "an old shepherd came to the infirmary in the most casual manner and presented the writer (Dr. Buchanan was then assistant to Reid) with a note from a doctor in Port Stanley, Falkland Islands. Surely Mackenzie's name has gone round the world more than once and is still good. Patients come from the uttermost ends of the earth to the infirmary, which was so largely made by his good name." Those who are interested in the beginnings of things should surely read this article.

\section{THE ADJOURNMENT OF THE INTERNATIONAL CONGRESS OF OPHTHALMOLOGY} (I925)

WE have received the following communication which we publish by the request of the General Secretary of the French Society of Ophthalmology:

Les Comités de la Société d'Ophtalmologie de Paris, de la Société Belge d'Ophtalmologie et de la Société Française d'Ophtalmologie, estiment nécessaire de déclarer à nouveau que ces Sociétés ont accepté, sans réserve, l'emploi de la langue allemande, langue scientifique ou familière de plusieurs peuples, comme langue officielle du Congrès de Londres;

Qu'elles sont résolues à collaborer avec les Nationaux d'AutricheHongrie, de Bulgarie et de Turquie;

Qu'elles se refuseraient à participer à ce Congrès si les Allemands y étaient invités. 